\title{
LEGAL-POLITICAL PARADIGM OF INDONESIAN CONSTITUTIONAL COURT: DEFENDING A PRINCIPLED INSTRUMENTALIST COURT
}

\author{
Mirza Satria Buana* \\ Lambung Mangkurat University, Banjarmasin, Indonesia \\ mirza.buana@ulm.ac.id
}

Received: 2 May 2018 | Revised: 20 March 2020 | Accepted: 1 April 2020

\begin{abstract}
The establishment of the Indonesian Constitutional Court in 2003 signified the formation of a bridge between the judiciary and politics. Through its judicial review process, there is a more tangible presence of the judiciary and court in the political arena. The Court helps with addressing moral predicaments and influencing the products of the legislature. This paper discusses the shifting of the legal-politico paradigm, particularly relating to judicial leadership of the Court because this significantly affects the role of the Court in the political arena. The history of the establishment of the Court's authority in judicial review is explored through a stylised analysis of the actions of two early Chief Justices. This paper also examines two Court decisions which illustrated the Court's authority on judicial review because they demonstrated the importance of policy-driven decisions and judicial restraint. The main argument of this work is that it is hard to categorize the legal-politico actions of the Indonesian Court into either legalism or instrumentalism. Often, the Court synthesises the two. The legal-politico paradigm is a dynamic one. The most feasible model of the Indonesian Constitutional Court is that of a Principled Instrumentalist Court, where policy decisions guide the formation of legislation according to constitutional values, but the judges maintain prudential self-restraint.
\end{abstract}

Keywords: Constitutional Court, Instrumentalism, Judicial Restraint, Judicial Review, Legalism.

Associate Professor at Faculty of Law, Lambung Mangkurat University, South Kalimantan, Indonesia. A Doctor of Philosophy (Ph.D) from TC Beirne, School of Law, University of Queensland, Australia. 


\section{INTRODUCTION}

In Indonesia's post-authoritarian context, the Court is often depicted as the manifestation of the constitutionalism principle. The Court guarantees that the supreme law of the land, the 1945 Constitution, maintains its position as a legal touchstone for the drafting and implementation of legislation. The Court also ensures a system of checks and balances in which political products can be

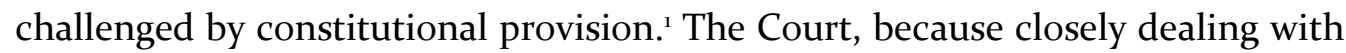
the constitutionality of legislation, often overlaps in action and works with the Legislature (the DPR) and Executive (the President) branches of government because they jointly draft and formulate legislation. ${ }^{2}$ Since its establishment in 2003, the Court has undergone and survived fluctuations in political dynamics and pressures. The Court has two options: first, it must uphold the doctrine of parliamentary sovereignty, meaning that the Court must only either uphold or strike down legislation. Second, the Court can act as a legal activist by highlighting political motives underlying the legislation under review. ${ }^{3}$ It is often questioned as to whether the Court takes part in legal activism or sliding politically progressive juristocracy. Each option presents different perspectives and results in a different outcome.

The Court's approaches to judicial review align with two contesting legal paradigms: legalism and instrumentalism. ${ }^{4}$ The former stresses the fidelity of law, meaning that the law's authority lies in its autonomy as a social system. It guarantees that judges' methods of legal reasoning must uphold impartiality and from political interest. In the practical realm, judges must be able to exclude the influence of political factors, including judges' personal preferences or their political loyalties. ${ }^{5}$ For the sake of analysis, it is important to note that legalism is more sociological than formalism. The latter stresses the rigidity of a law,

\footnotetext{
Suri Ratnapala, "The Idea of a Constitution and Why Constitutions Matter," Policy, (Summer, 1999/2000): 3. As stipulated in Article 5 (1) and Article 20 of the 1945 Constitution (as amended).

Mirza Satria Buana, "Hubungan Tarik-Menarik antara Kepastian Hukum dan Keadilan Substansial dalam Putusan MK [Substantive Justice and Legal Certainty on the Constitutional Court's decisions]" (LLM Thesis, Islamic University of Indonesia, 2010), 45.

4 Theunis Roux, "Indonesia's Judicial Review Regime in Comparative Perspective," Constitutional Review 4, no. 2 (December, 2018): 192.

Ibid., 200.
} 
claiming that law is a close-logical system and independent from nonlegal or sociopolitical influences. ${ }^{6}$ Formalism extols the classical notion of the separation of power, implying that the judiciary must not interfere with the tasks of the Legislature and Executive branches by deconstructing the meaning of legislation. Judges, in this respect, can only 'find' the law, and are prohibited from creating the law. 7 In contrast, in legalism, the judges are allowed to be creative if there is 'open texture' in the written law. ${ }^{8}$ Despite these differences, both legalism and formalism share a prescriptive account; law should be elaborated on what the law and its institutions should do. As a result, they prefer legal abstraction, rather than an empirically provable fact.

In contrast, instrumentalism is closely related to legal realism. Nonetheless, it also has several differences. Legal realism characterizes law as a flexible entity that can be either influenced by or influence, sociopolitical and economic realms. ${ }^{9}$ However, legal realism relates more to a descriptive theory, while instrumentalism as the heart of the theory offers a practical answer for a legal problem. Instrumentalism is inherently pragmatic. It is known as 'pragmatic instrumentalism' which has several practical aims. First, it considers law not as an autonomous and self-sufficient system, but as merely an instrument to reach external-substantive goals that are derived from sources outside the law. Second, it treats 'the law in action' which considers the nature of law through social means. Thus, law science and legal institutions must resort to social sciences in order to construct a policy. ${ }^{10}$ Third, in practical terms, the judiciary through judicial review can create and modify legislation under review in order to fit with the sociopolitical and economic conditions. In other words, the court modifies legislation under review to meet contemporary needs, circumstances, and interests.

\footnotetext{
Arthur Lenhoff, "On Interpretive Theories: A Comparative Study in Legislation," Texas Law Review 27 (1949): 313. Donald Gifford, Statutory Interpretation (Sydney: The Law Book Company, 1990), 49.

H.L.A. Hart, The Concept of Law (Oxford: Clarendon Press, 1994), 132.

John C. Gray, The Nature and Sources of The Law (New York: The Macmillan Company, 1938), 100.

10 Robert S. Summer, "Pragmatic Instrumentalism in Twentieth Century American Legal Thought - A Synthesis and Critique of our Dominant General Theory about Law and its Use," Cornell Law Review 66 (1981): 863.
} 
The Indonesian Constitutional Court has a history of dynamic shifts in guiding the legal paradigm. Legalism, with a constrained court and principled judges, gave way to instrumentalism and its relatively instrumentalistunconstrained court characterized by strategic policy decision-making." This instrumentalist court easily slid into acting as a political court, positing itself as a solely political, rather than a legal actor. ${ }^{12}$ This assertion can be evidenced by the appointing of Akil Mochtar, a former politician, to the Court as first a Justice and then the third Chief Justice in early 2013. The decision ultimately proved to be a mistake: Akil was arrested over bribery charges. ${ }^{13}$ It became clear that the Court was not immune from politicisation, suddenly lost public confidence. Akil's involvement within the court system has been considered a 'Trojan Horse' strategy to weaken judicial power from within. ${ }^{14}$ Bribery involving a judge occurred again in 2017 when Justice Patrialis Akbar was charged with accepting a bribe of USD 70,00o and IDR 4.043 million to grant a judicial review to a case involving businessmen's interest in Livestock Law. ${ }^{15}$ In these two cases, the Court failed to systematically withdraw all matters of political interest from the competence of the judiciary. ${ }^{16}$ These two cases of judicial corruption cases demonstrate that an instrumentalist court is prone to political influences, which could determine how the Court behaves. And, this politically influenced court could tarnish the integrity of the overall Court itself. Thus, this paper aims to revisit the concept of an instrumentalist court and suggest a more principled instrumentalist court.

This study discusses the dynamic of the legalpolitico paradigm of the Constitutional Court: legalism and instrumentalism, particularly relating to

\footnotetext{
${ }_{11}$ Theunis Roux, "American Ideas Abroad: Comparative Implications of U.S. Supreme Court Decision-Making Models," International Journal of Constitutional Law 13, no.1 (2015): 33.

12 Roux, "Indonesia's Judicial Review," 207.

13 The Jakarta Post Online, "KPK names Akil Mochtar suspect of money laundering charges," The Jakarta Post, 26 October 2013, http://www.thejakartapost.com/news/2013/10/26/kpk-names-akil-mochtar-suspect-moneylaundering-charges.html.

14 Feri Amsari, "Kuda Troya bagi MK [Troy's Horse strategy for demising the Constitutional Court]," Kompas, 4 April 2013.

15 Tempo.com, "Patrialis Akbar Charged for Accepting Bribes," Tempo, 13 June 2017, https://en.tempo.co/read/ news/2017/06/13/055884133/Patrialis-Akbar-Charged-for-Accepting-Bribes.

16 Tim Lindsey, "Indonesian Trial Process and Legal System, Background Notes" (Unpublished Paper).
} 
judicial leadership of the Court, because this significantly affects the role of the Court in judicial review and the political arena. This issue is inspired by the United States (U.S) Supreme Court, in which there has been a debate between legalism and realism perspectives. ${ }^{17}$ This study scrutinizes the ideal role of the Court and its judges in the current form of Indonesia's democracy. It contemplates several Court decisions in the light of the bias of the Court towards certain political influences. The decisions provide partial evidence for the best way the Court sought to legitimate its decision. The public expects that the Court can tame or lessen political interests in both the substance and implementation of legislation through its judicial review. Besides its progressive role in the political arena, the public also demands that the Court be held accountable in its exercise judicial review authority.

First, both the legal and political contexts of the Court will be presented. This section stresses the shift in judicial leadership influenced by legalism court to that of instrumentalism. The shift reflects the legal paradigm of the Court and its approach to addressing demands for constitutionality in legislation. This section also presents previous attempts by the Court to politically restraint its judicial review in order to soothe the tensions with the DPR. In these instances, the Court introduced 'conditional' decisions. The following section highlights two decisions that illustrate the importance of defending the Court's instrumentalist nature to preserve constitutional values and the rule of law principle. One decision illuminates the political and functional importance of prudential restraint in the Court. The aim of restraint is to prevent the Court from becoming 'political court' and to promote its accountability and integrity. The following section presents a realistic model of what a 'balanced-court' may look like as one based on principled instrumentalism.

${ }_{17}$ Brian Z. Tamanaha, Beyond The Formalist-Realist Divide: The Role of Politics in Judging (New Jersey: Princeton University Press, 2010). 


\section{SHIFTING LEGAL PARADIGM: A QUESTION OF LAW'S AUTHORITY18}

Politics have strongly influenced the formation of Indonesia's rule of law; politics often determine whether or not a law may be effectively constructed. Since early independence, politics have prevailed over aspiration for a more reliable rule of law. As an example, President Soekarno, in his Demokrasi Terpimpin (Guided Democracy), prioritized state security over human security by attaching law enforcement institutions, including the Police, Public Prosecutor and Judiciary under his executive power while lessening participatory democracy. ${ }^{19}$ The idea of constitutional sovereignty through judicial review had been recognized, but could not be materialized because it was considered too liberal. ${ }^{20}$ The law and its institutions were merely used as 'tools' for 'Soekarno's revolutionary dream.' The next regime, President Soeharto, more and less preserved and modified those previous authoritarian settings and further developed an illiberal rule of law in a more sophisticated way. As a result of more than 23 years under authoritarian governance, Indonesia's rule of law is still strong political, and whether democracy has been realized is still being contested. ${ }^{21}$

Amidst the constitutional amendments process from 1999-2002, ${ }^{22}$ Indonesia's rule of law has undergone several changes and dynamics. First, the constitutional amendments process removed the wording rechtsstaat from the 1945 Constitution. The removal sparked interpretation regarding Indonesia's legal paradigm. Many believe that Indonesia's current legal paradigm is no longer aligned with the Civil Law tradition. It is significantly influenced by the Common Law and other legal traditions, including the international and comparative laws. ${ }^{23}$ This

\footnotetext{
18 This section is greatly influenced by Roux's works. See Roux, "Indonesia's Judicial Review." See also Theunis Roux, "American Ideas Abroad," 90-118.

19 Fachrizal Afandi, "The Justice System Postman: The Indonesian Prosecution System at Work," in The Politics of Court Reform: Judicial Change and Legal Culture in Indonesia, ed. Mellisa Crouch (Cambridge: Cambridge University Press, 2019): 88.

20 Saldi Isra, "Gagasan Bernegara Yamin [Yamin's Suggestion on Nation-State]," Koran Tempo, 2 September 2014.

21 Endy M. Basuni, "Indonesia's Democracy Alive, but Needs More Kicks," The Jakarta Post, 17 July 2019.

22 The amendment of the 1945 Constitution underwent four stages: first was on 19 October 1999, the second was on 18 August 2000, the third was on 9 November 2001, and the last stage was on 10 August 2002.

23 Buana, Hubungan Tarik-Menarik, 101.
} 
interpretation affects the approaches employed by judges to dispute resolution and legislation interpretation and review.

Second, the second stage of the constitutional amendment process involved the transplanting of international human rights norms into national law. This process demonstrates that the government must comply with international human rights norms. Consequently, the Court has to adapt to an international context and develop through allowing 'constitutional borrowing' in court decisions and its interpretation. The adoption marked the beginning of the age of internationalization of constitutional law in Indonesia. ${ }^{24}$ The legal transplant forced Indonesian jurists to be more open-minded and think globally; jurists were suddenly required to master national law and understand comparative law methodology. Diverse approaches to interpretation have challenged the old-school paradigm of simple syllogism.

While Indonesia's law was still undergoing a transition from semi parliamentarism into presidentialism, the People's Consultative Assembly (MPR) impeached President Abdurrahman Wahid (known publicly as Gus Dur) without a strong legal base. In learning from the preceding experience, the next administration, President Megawati Soekarnoputri and her political party (PDI-P) argued for the importance of the Constitutional Court in scrutinizing the mechanism of impeachment. ${ }^{25}$ This argument is the real political reasoning behind the establishment of the Court (occasio legis). Today, the Constitutional Court is known for its crucial mandates: to review the legislation according to the Constitution, ${ }^{26}$ to make a ruling on disputes between state institutions, to order the dissolution of political parties found in violation of the Constitution, to issue binding verdicts on contested election results, and to oversee and evaluate

24 Bisariyadi, "Referencing International Human Rights Law in Indonesian Constitutional Adjudication," Constitutional Review 4, no. 2 (2018): 251.

25 Stefanus Hendrianto, "From the Humble Beginning Law to The Functioning Court: The Indonesian Constitutional Courts 2003-2008" (Doctoral Dissertation, University of Washington, 2008), 44.

26 The Court combines two approaches to judicial (constitutional) review. The judges can conduct either a material or substantial review, or a formal review. A substantial review covers theoretical and philosophical aspects of the legislation and traces congruency of the legislators' intention regarding the Constitution. On the other hand, a formal review can be divided into two aspects: an examination of both the legislature's legal authority and of its procedural aspects. See, Internal Regulation of the Constitutional Court No 06 of 2005 on Procedural Code, art 4. 
impeachment processes. ${ }^{27}$ It is important to note that the Court cannot review other types of laws below the level of legislation, as these types of laws fall within the review jurisdiction of the Supreme Court. ${ }^{28}$ Neither can the Constitutional Court review the constitutionality of subordinate regulations, as the Supreme Court only can review regulations made under any law against such law. ${ }^{29}$

By establishing the Constitutional Court, Indonesia has adopted a contemporary legal discourse: judicial politics. It depicts the presence of political influences on judicial behaviour. In this way, the Court plays a significant role in addressing moral predicaments and controlling the products of the legislature and the conduct of the executive. It also maintains the more tangible presence of judicial process and court rulings in the political spectrum..$^{30}$

Philosophically speaking, the abovementioned changes and dynamics have moulded the Court into a 'salad bowl' institution, which employs judges with diverse legal paradigms, including legalism and instrumentalism. Despite the diversity of judges, the role of judicial leadership, held by the Chief Justice, is crucial in shaping the Court's paradigm. To analyse dynamics inside the Court, this study first traces the Court's legal foundation which was established using a legalism perspective.

\subsection{Legalist Inspired Court}

In its first years of establishment, Prof Jimly Asshiddihiqe, a constitutional professor at the University of Indonesia, chaired the Court. In order to strengthen its position as a new judiciary body, the Chief often expressed many jargon considering the importance of the Court, such as: " (The Court) as the Guardian of the Constitution", and "The Sole Interpreter of the Constitution." ${ }^{11}$ Moreover,

\footnotetext{
${ }_{27}$ Article $24 \mathrm{C}$ (1) and (2), the 1945 Constitution.

${ }_{28}$ Regarding the split authority between the Supreme Court and the Constitutional Court, Article 24A (1), the 1945 Constitution (Amended) (Indonesia) states: "The Supreme Court shall have the authority to ... review ordinances and regulations made under any law against such law." See Simon Butt and Tim Lindsey, "Economic Reform when the Constitution Matters: Indonesia's Constitutional Court and Article 33," (Bulletin of Indonesian Economic Studies 44, 2008), 242.

29 Tim Lindsey, "Filling the Hole in Indonesia's Constitutional System: Constitutional Courts and the Review of Regulations in A Split Jurisdiction," Constitutional Review 4, no. 1 (2018): 28.

30 Bjorn Dressel, "Governance, Courts and Politics in Asia," Journal of Contemporary Asia 44 (2014): 265.

${ }^{31}$ Jimly Asshidiqie, Konstitusi dan Konstitusionalisme di Indonesia [Constitution and Constitutionalism in Indonesia] (Jakarta: KonPress, 2006), 7.
} 
the Court's architecture also resembles a Roman building, with its nine pillars representing the nine Justices of the Court, imitating the nine Justices in the US Supreme Court. All of these jargons and infrastructure images were used to strengthen the notion of legal autonomous and the principle of the rule of law.

Prof Asshiddiqie established the foundation of the Court as the spearhead of Indonesia's rule of law by stressing its judicial independence. Simply because there will be no legal supremacy without the independence of the judiciary. ${ }^{32}$ The Court had tried to accomplish prerequisites for the independence of the judiciary such as, judges' personal independence legally guaranteed for the term of office and tenure, judges' freedom from colleagues' influences, collective independence allows independence to participate and regulate the court's budgeting, and lastly, the court substantive independence which manifests itself when deciding cases. ${ }^{33}$ The first three prerequisites relate to the general judiciary reform agenda to separate the judiciary from the Ministry of Justice, ${ }^{34}$ while the last prerequisites relate to the Court's fairness and impartiality which should be examined from its decisions.

In that period, the Court enjoys a high degree of judicial independence and involvement in the political arena. ${ }^{35}$ Under the judicial leadership of Prof Asshiddiqie, the Court exercised the technical function of the Court which has duties to sustain and deduce legal propositions. It must apply, define or reinforce rules or doctrines, which eventually contribute to strengthening the structures of the social order. ${ }^{36}$ To boost the technical quality of its decisions, the Court developed consistent standards for judges' reasoned opinions with declaratory style, ${ }^{37}$ and encouraged judges' freedom to write his own individual opinion. This Anglo-American judgements style allows judges to express their perspectives and reasoning through either a concurring or dissenting opinion..$^{8}$

32 Shimon Shetreet, "Judicial Independence: New Conceptual Dimensions and Contemporary Challenges," in Judicial Independence: The Contemporary Debate, ed. Jules Deschenes and Shimon Shetreet (M.Nijhoff: Hingham, 1995), 58.

33 Ibid., 59.

34 Daniel S. Lev, "The Politics of Judicial Development in Indonesia," Comparative Studies in Society and History 7, no. 2 (1965): 173-199, 174.

35 Dressel, "Governance, Courts and Politics," 264.

${ }^{36}$ Martin Shapiro, Court: A Comparative and Political Analysis (Chicago: University of Chicago Press, 1981), 15.

37 Simon Butt (2015) in Roux, "Indonesia's Judicial Review," 192.

38 Arne Mavcic, The Constitutional Review (Den Bosch Netherlands: Book World Publications, 2001), 76. 
Despite this, there is a freedom of judges to express their own opinions based on their legal paradigm. This legalist court still embedded with technical jurisprudence. ${ }^{39}$ This attitude is a result of strong civil law tradition, especially from Kelsen's doctrine, stating that the law has its self-legitimation which corresponds to objectivity. In other words, it contains analytical objectivity, which means that the state and the law are an objectively logical-formal structure. ${ }^{40}$ Similarly, the common law also has legalism tradition represented by Austin who firmly states that law is objectively rational, rather than intuitive, political or ideological. And it has the dynamic that allows it to be self-supporting and self-developing and is neutral from social controls. ${ }^{41}$

As a result of its philosophical standing, the legal construction or modification should start from an internal point of view because the legal system is a closed logical system: the judge endeavouring to trace the legislative intent of the legislation (historical jurisprudence). Legislative intent is synonymous with the civil law's concept of ratio legis. ${ }^{42}$ Statutory interpretation, in the civil law tradition, is referred to as the law finding (rechtsvinding) process in which the judge endeavours to 'find' a hidden legal question within the internal system of the law. The judges should provide the sole basis for determining the essence of the enactment. Their purpose is to seek to investigate the ascertainment of the intent or purpose underlying the enactment in question. ${ }^{43}$

The rigidity of judges' interpretation in civil law tradition must be sought in the nature of the inquisitorial system and the absence of the jury system. The judge becomes the only one who creates a balance between certain rules and the justice of the particular case. ${ }^{44}$ Furthermore, in Indonesia's legal context, the Dutch colonial law, Algemene Bepalingen (AB) [General Provision] art 20 stated that "the judge must decide the case according to the legislation." Even though the Dutch legislation is no longer valid, the majority of judges often consider

\footnotetext{
Slightly similar to what Pound said as 'mechanical jurisprudence' in Roux, "American Ideas," 11.

40 Hans Kelsen, The Pure Theory of Law (California: University of California Press, 1967), 3.

$4_{1}$ John Austin, The Province of Jurisprudence Determined (London: Weidenfeld and Nicolson, 1954), 117.

$4^{2}$ Lenhoff, "On Interpretive Theories," 325.

43 Ibid.

44 Ibid., 334. An inquisitorial court gathers evidence for itself, without discarding unfavourable evidence. It is centralised in nature.
} 
'law' to be merely legislation. ${ }^{45}$ This attitude occurs because the legislation does not explicitly explain the meaning of 'law' in that Act and its articles. And it creates overly reliant on civil law tradition and approaches. In that way, judges of the Court are considered as 'gatekeepers' of their country's legal tradition. ${ }^{46}$

Furthermore, this technical function requires a non coercive approach to the DPR and the Executive, as institutions that have original intent of the legislation. Parliamentary sovereignty should be respected because the only law is that which is created by the state via the legislature, and it should be reduced to the form of legislation. ${ }^{47}$ This technical function is represented by the judicial presumption of the constitutionality of legislation. It embraces the idea of strict interpretation which has the advantage of certainty and predictability but with the possible disadvantage of injustice. $4^{8}$

To soothe the tension, the Court has modified its decisions by declaring a 'conditionally' decisions, in two scenarios. First, conditionally unconstitutional means that the submission is granted conditionally by declaring the legislation unconstitutional, but allows the executive and legislature to revise the legislation based on the requirements and interpretation of the Court. Second, conditionally constitutional means that the review is rejected conditionally. The Court raises questions about the constitutionality of the legislation but refuses to invalidate it. Instead, the Court provides both the executive and legislature with some requirements and interpretation of the Court. The future constitutionality of the legislation depends on how it is enforced. ${ }^{49}$ By changing the nature of its decisions, the Court can act cautiously in refashioning the legislation. According

45 Elisabeth Nurhaini Butarbutar, "Kebebasan Hakim Perdata dalam Penemuan Hukum dan Antinomi dalam penerapannya [Freedom of Judge: Law-finding and Antinomy]," Mimbar Hukum 23 (2011): 70.

46 Joseph Raz, Ethic in The Public Domain: Essay in The Morality of Law and Politics (Oxford: Clarendon Press, 1996), 359 .

47 Giorgio Bongiovanni, "Rechststaat and Grundnorm in the Kelsenian Theory," in Legal System and Legal Science (The Hague: ARSP, 1997), 65.

48 Michael Kirby, The Judges (Sydney: Australian Broadcasting Corporation, 1983), 61.

49 Simon Butt, "Conditional Constitutionality, Pragmatism and the Rule of Law" (Legal Studies Research Paper No. 09, 28, The University of Sydney, 2009), 1. Additionally, it is also important to note that the Court has regular type of decision outcomes, such as: the submission is granted. This means the legislation is unconstitutional; the submission is granted partially. This means not all submissions are granted; the submission is rejected, that is, the legislation under review is constitutional; And lastly, the application of review cannot be accepted by the Court, is inadmissible, due to the lack of legal standing. 
to Siregar, there were moments when the Court refrained from its activism to avoid confrontation with the DPR..$^{\circ}$

Moreover, with regard to the 'conditionally' outcome, the legislation that had been reviewed can be reviewed again if either the executive or the legislative powers do not follow the Court's requirements and interpretation. In this respect, the Court has an exception to the nebis in idem principle: the applicants can re-submit their review application concerning the same legislation that had already been decided by the Court. However, the claimant must use a different constitutional article as a touchstone to review the legislation. ${ }^{51}$

It is clear that the rationale of 'conditionality' in the Constitutional Court is to make its decision more politically palatable..$^{52}$ This is the practice of politics of judiciary which the Court exercises its political self-restraint. ${ }^{53}$ The Court tries to restraint its power to interfere with the legal drafting process and attempts to emphasize its role only as a legalism court. Nevertheless, in its legal paradigm development, the Court had slightly shifted its paradigm when the Court entirely abolished the Law of State Electricity as it considered the legislation too liberal and in breach of national interest. ${ }^{54}$ In this decision, the Court used 'state ideology'-Pancasila -as its dominant reasoning. ${ }^{.55}$

By considering ideologies as judicial reasoning means that the Court accepted the notion of ideologically strategic decision-making, which is under the realm of institutionalism, where the Court acts strategically to create policy and considers external influences to legislation. In this regard, the legalist court acts more in line with theories related to sociological thought than formalist thought. When the Court considers 'state ideology' meaning that it has expressed its autonomy as a social system and a dominant cultural ideology. ${ }^{56}$ Prof Asshiddiqie also

\footnotetext{
Fritz E. Siregar, "Indonesia Constitutional Court Interpretation Methodology (2003-2008)," Constitutional Review 1, no. 1 (2005): 3 .

51 Internal Regulation of the Constitutional Court No 6 of 2005 (Indonesia) art 42. This regulation is an exception of Law No 24 of 2003 (Indonesia) art 60.

52 Butt, "Conditional Constitutionality," 2.

53 Richard A. Posner, "The Meaning of Judicial Self-Restraint," Indiana Law Journal 59, no. 1 (1983): 12.

54 Judicial Review of State Electricity Law, Decision of Constitutional Court No: 001-021-022/PUU-1/2003.

55 lbid.

${ }^{56}$ Roux, "Indonesia's Judicial Review," 199.
} 
agrees to some extent with 'judge-made law', if it is needed for judicial interest. Judge's decision, as a logical construction, can construct the new meaning of legislation with there is any legal vacuum. ${ }^{57}$ Nevertheless, the legal vacuum becomes the one possible condition to construct the new meaning of legislation. Prof Asshiddiqie's intellectual standing has similarities with Hart's inclusive approach to decision making. Hart re-opened the opportunity to strengthen the role of the court by encouraging judges to use their discretion in making new laws or filling the gaps if the written laws were too general, unclear or defective..$^{8}$ The judges are allowed to be 'creative' if there was 'open texture' in the written law. It is clear that legalism can accommodate judicial creativity in various well-known ways.

Despite the fact that legalist courts have developed into more sociological mindsets, this paper argues that legalism alone is an insufficient guide for judges' legal reasoning. A legalist mindset should mingle with external aspects of law, including politics and social justice aspirations. When the political condition becomes more complex and discriminatory, the Court needs to step in to employ strategic policy-based decisions that are sensitive to social needs. It is a prescriptive account of what the Court should do. Instrumentalist-baseddecision-making has enriched the Court's decisions. This article argues that legalism is still an important foundation for understanding the rule of law and constitutionalism, but instrumentalism, with restraints, is often a more realistic choice.

\subsection{The Rise of Instrumentalist Court}

The rise of instrumentalist Court is depicted when Chief Justice Mahfud MD began to articulate the law's authority in the form of 'substantive justice' approach to judicial decision-making. Philosophical concepts such as justice, equity and fairness became more reliant as touchstones in determining the constitutionality of legislation. ${ }^{59}$ In this era, the Court could resolve an immediate

\footnotetext{
57 Jimly Asshiddiqie and Ahmad Syahrizal, Peradilan Konstitusi di Sepuluh Negara [Comparison of Ten Constitutional Courts in the World] (Jakarta: Sekretariat Jenderal dan Kepaniteraan Mahkamah Konstitusi RI, 2006), 11.

$5^{8}$ H.L.A. Hart, The Concept of Law, 132.

59 Buana, Hubungan Tarik-menarik, 110.
} 
political issue; by not only reviewing legislation under review but also making new norms to fit social justice aspiration. This legal paradigm comes with the advantage that justice may be satisfied, but has the disadvantage of uncertainty and inconsistency. ${ }^{60}$ Instrumentalism court should be critical when it reviews legislation because legislation is the product of politics. This position is represented by the judicial presumption of unconstitutionality and embraces the idea of judicial activism. Nevertheless, it is also important to note that just because legislation is a function of politics, it does not mean that the law's authority is a function of politics. The impartiality and neutrality of the legal drafting methods in which political mandates are interpreted and applied are guarantee Law's authority.

The critical point of view toward legislation departs from the assertion that the legal ontology of the legislation is constructed by social experiences, which are substantially subjective, intuitive and practical. ${ }^{61}$ Therefore, enacted legislation is not necessarily filled by positive values; it may be ill-intended and politically opportunistic. ${ }^{62}$ Legislation can thus be seen as an ideology compromised by the status of domination.

Instrumentalism expands the judicial reasoning from ratio legis into occasio legis, a concept that posits both the political and social condition as the real reason for the enactment of the legislation. ${ }^{6} 3$ In this regards, the Court engages with its ideological function, which involves the maintenance of currents of ideology which legal doctrine maintains, implements and serves to legalise government and empower the social order. ${ }^{64}$ The state governs and transmits its ideology to the people through the court decisions by applying the law to the cases. ${ }^{65}$

Mahfud MD once admitted that "since I have authority (as a Chief Justice), I will do ijtihad (legal contemplation in Islamic law's concept) to progressively

\footnotetext{
6o Kirby, Judge, 61.

${ }_{61}$ Luiz Fernando Coelho, "A Contribution to a Critical Theory of Law", in Legal Philosophy: General Aspects: Concepts, Rights and Doctrines, ed. Michel Troper and Annalisa Verza (Steiner, 2002), 34.

62 lbid.

63 Lenhoff, "On Interpretive Theories," 325.

${ }_{64}$ Shapiro, Court: A Comparative and Political Analysis, 228.

65 Ibid.
} 
change unfair legislation." ${ }^{66}$ This pro-justice and policy-preference-maximiser attitude is supported by the principle of non liquet or ius curia novit, ${ }^{67}$ meaning that a judge cannot avoid offering or reasoning through to a solution, even though there is a lack of clarity in the law. ${ }^{68}$ As a result, justice is in the hands of the judge. This principle is confirmed by the positive law on Judiciary Law stating that "the court cannot reject a case brought by disputants even where the law is absent, unspecific or vague. ${ }^{69}$ This norm can be interpreted in two ways: first, the judge can be creative by finding the law, but only through the law's internal values, as in the legalism perspective. Second, the judge can endeavour to 'create' and 'modify' legislation by considering external values that could be sociological and even political. Mahfud MD clearly employed the latter approach.

This norm obliges the judges to know all about the legal aspects of legislation. It opens possibilities for judges to be more creative in constructing their legal reasoning. The Judiciary Law states, “...judges both in the Supreme Court and the Constitutional Court systems must also understand, elaborate and rely on customary or unwritten law." ${ }^{\circ}$ These two articles should be considered as legal norms guiding judges to not only decide cases according to the law (text of legislation) but to maximize all materials both written and unwritten, legally, sociologically and even politically. As mentioned in the previous discussion on legalism, there are principle states that 'the judge must decide the case according to the law.'71 The word 'law' should be interpreted in a broad sense, which also includes unwritten laws and social justice aspirations.

The reliance on the internal aspect of legislation is one of the areas of critics. Legalism claim that the 'truth' of the legislation can be found internally through historical enquiry of legislative intent. However, finding legislative intent

\footnotetext{
66 Informal discussion with Prof Mahfud MD, when author attended his lecture.

67 Bagir Manan, "Kekuasaan Kehakiman [Judicial Power]" (Paper presented at General Lecture, Airlangga University, 1 December 2011), 8.

68 Noel Struchiner, "The Meaning of Justice," in Legal Philosophy: General Aspects: Concepts, Rights and Doctrines: proceeding of the $19^{\text {th }}$ World Congress of the International Association for Philosophy of Law and Social Philosophy (IVR), ed. Michel Troper and Annalisa Verza (New York, June 1999), 112.

69 Article 10 (1), Law No 48 of 2009 on Judiciary.

70 Article 5 (1), Law No 48 of 2009 on Judiciary.

${ }_{71}$ Article 4 (1), Law No 48 of 2009 on Judiciary
} 
has a fundamental flaw. It divorces legislation from its contemporary context. By using legislative intent, the court applies a retrospective perspective, not a contemporary or prospective point of view. Legislative intent is a myth because legislators have many intentions and interests. The intentions are not always wise. It may be political and pragmatical. Thus it is impossible to trace the true intention of the legislation. Furthermore, Corcoran states that the discerning legislative intent approach in statutory interpretation is insufficient..$^{72}$ There are areas of concern missing, including contextual problems, the indeterminacy of language, and the validity of extra-legal norms.

Additionally, over-reliance on the legislation could result in oversimplification because legislation presents only a small part of the law; most legislation is rooted in the nature of social relations, which change as social conditions change. ${ }^{73}$ Today, this approach is balanced by the minor doctrine of equity, which is distinguishable from the rigidity of the laws. When the main object of legislation is unreasonable and unjust, judges are at liberty to expound the statute by equity to disregard it.

It is also important to note that instrumentalism does not aim to eradicate fidelity of law but endevour to set law's authority as contingent, not on its autonomy from politics, but law's usefulness as an instrument for the pursuit of a political goal. ${ }^{74}$ The idea of constitutionalism is still embraced. This idea relates to a law's authority and how this authority is still guided by the constitution. It functions as the most paramount legal touchstone. Thus, it must be able to oversee and tame the political interests on legislation under review. The Court's Justices have taken an oath to respect and uphold the constitution. Thus, they have an obligation under the constitution to defend it from encroachment and the misleading law-making processes of legislators. In other words, constitutional validity must surpass the principle of democracy. In this sense, legislation as a manifestation of the 'people's voice' is inferior to legal supremacy, represented

\footnotetext{
72 Suzanne Corcoran, "Theories of Statutory Interpretation," in Interpreting Statutes, ed. Suzanne Corcoran and Stephen Bottomley (Sydney: The Federation Press, 2005), 30.

73 Lenhoff, "On Interpretive Theories," 326.

74 Roux, "Indonesia's Judicial Review," 198.
} 
by the judiciary. It is contended that majority rule is denied in principle by constitutionalism through judicial review.75

Nevertheless, political nuances are real in constitutional law dynamics. Legislation must be seen realistically as a mere projection of political power. It is not really a 'people's voice' drafted through legislative drafting, but it is not always purely derived from the people's aspirations. Instead, it can be based on compromised dealing. ${ }^{76}$ Lastly, legislation is static, often out-of-date with current and progressive social and political changes. Thus, the Court must step forward to interpret, review and contextualise the legislation to fill in any gaps in the legislation. In this regards, the law's authority derives from the desirability of the outcomes it produces. ${ }^{77}$

When the Court has become more instrumental by heroically reviewing and changing legislative intent, the DPR started to fight back by revising the Constitutional Court Law. The next section highlights the Court's decisions that depict contestation of aspirations between the DPR that wanted the Court to be strictly legalism or even worse, a formalist court, and the Court that defends its independence of judiciary.

\section{THE DISCOURSE OF LEGAL-POLITICO PARADIGM'S THROUGH JUDICIAL REVIEW}

There are two Constitutional Court's decisions that effectively represent the opinions on whether the Court should respect parliamentary sovereignty or creatively change the wording of legislation in creating policy. These two decisions were crucial because they challenged the revised Constitutional Court Law by the DPR. The revised Law was a political response to the practice of the 'Progressive Court' under Mahfud MD's judicial leadership. In these two decisions, there were three important legal questions. The first is related to whether the Court had the power to declare constitutionality of articles that are

75 Ibid., 182.

76 Mohammad Mahfud MD, Politik Hukum di Indonesia [Policy-Oriented in Indonesia] (Jakarta: Rajawali Press, 2009), 22.

77 Roux, "Indonesia's Judicial Review," 200. 
not demanded by parties and expand its decisions to other legislation's articles under review. The second is related to whether the Court could stipulate or insert policy or new norms into legislative articles under review. The third is related to whether the Court has the power to utilize other related legislation as constitutional touchstones.

\subsection{Surpassing an Applicant's Demands}

The first Court decision ${ }^{78}$ targeted two important articles in the 2011 Constitutional Court Law. ${ }^{79}$ The first was Article 45A, which states: "The Court's decision is restricted to declare the unconstitutionality of article that is not demanded by applicants." The judges decided that the Court has the power to surpass the applicant's demands in its decision because the Court's decision dealt with the public interest. The decision affected not only the applicants but also all citizens of Indonesia (erga omnes). The Court also argued that articles under review are systematically interrelated..$^{80}$ Legalism influenced this decision because it is a legalist belief that legislation is a systematic legal building block within which articles are inter-linked provisions. Thus, this type of Court decision is unavoidable, and it is the essence of judicial review. Lastly, the judges must follow the demand of the applicant to provide a justiciable decision (ex aequo et bono). In addition to this reasoning, the Court also employed comparative insight by referring to the practice of the Korean Constitutional Court which allows the Korean Court to declare unconstitutionality on the whole for selected articles in legislation under review. However, the Court's reasoning did not consider the notion of independence of the judiciary that the applicants stressed in their demand. Article 24 (1) of the 1945 Constitution states that "the judiciary (including the Constitutional Court) is an independent institution which aims to elevate the rule of law and justice."

Besides the fact that the systematic aspect of the legislation was inspired by legalism, this decision also employed an instrumentalism perspective. The Court, for the sake of legal development, can and must expand upon the legal

\footnotetext{
78 Judicial Review of Constitutional Court Law, Decision of Constitutional Court No 48/PUU-IX/2011.

79 Law No 8 of 2011 on Revision of Law No 24 of 2003 on Constitutional Court Law.

80 Judges' Consideration, Decision of Constitutional Court No 48.
} 
questions demanded by the applicant. The Court's Justices have taken the vow to respect and uphold the constitution by interpreting and contextualizing the constitutional norms. Justices have an obligation under the constitution to defend it from encroachment and misleading law-making processes by legislators. This is the manifestation of the Court's ideological function. Historically speaking, this practice had developed judicial review practice, as evidenced by the landmark decision of Marbury v. Madison by the US Supreme Court. In this case, the US Supreme Court surpassed the demand of the applicant through its verdict. In other words, the practice of judicial review in the Indonesian Court was inspired by the instrumentalist thinking of the US Supreme Court. This decision reaffirms that the Court possesses the authority to surpass applicant's demands in order to fulfil the bigger outcome of law reform: substantial justice. The Court is the main expounder of the Constitution.

This issue of surpassing an applicant's demand combined two perspectives into a cohesive whole. Legalism inspired this decision by emphasizing the interlinkage of legal norms within the legislation. Invalidating a norm or norms would potentially change the whole meaning of legislation under review. Additionally, instrumentalism also enriched this decision by stressing the importance of public and contemporary needs of the decision. Judicial review of legislation has strong public law influences where this decision will bring significant effects to the public. Thus, the Court has an obligation to fulfil public sentiments on justice and legal certainty.

\subsection{Decision based Policymaking}

The ability of the Court to make law and policy is hotly debated. The second article under review was Article 57 (2a), which stipulates: "The Court's decision was restricted to stipulating or inserting policy or new norms into legislative articles under review." It is a controversial article that prevented the Court's judges from becoming 'positive legislators'. The DPR's representatives in the Courtroom stressed that the authority of the Court is only to declare whether the legislation under review is either constitutional or unconstitutional, and not to express policies or new norms. The DPR argued that the Court must respect 
the classical notion of separation of power (Trias Politica). ${ }^{81}$ In other words, the DPR wanted the Court only to exercise its technical functions. Blackstone had criticized this attitude toward the judges as their identity being that of the 'living oracles of the law' because the judges act only as passive receivers rather than an active and creative creator of law. ${ }^{82}$

The judges rejected the DPR's arguments. The Court declared that the article under review was unconstitutional because it hindered the noble aim of the Court to uphold the rule of law, constitutionalism and justice. The policydriven decision-making is crucial for filling the 'legal vacuum' of legislation under review. The legislative review processes take time and may be delayed by politics, so the Court must progressively fill the 'vacuum'. It is important to note that the reason for decision-making policy preference is not only because of a legal vacuum but to fulfil social justice aspiration.

As an instrumentalist institution, the Court and its Justices must wholeheartedly embrace social nuances and surroundings while conveying affirmative action in decision-making. Legalism argues that judges should be neutral. However, remaining neutral in unjust and discriminatory circumstances can be naive and lead to further injustice and discrimination. This policy preferences decision corresponds with Holmes' perspective on the role of the judge lawmaking: "I think that the judges have failed to adequately to recognise their duty in weighing the considerations of social advantage. The duty is inevitable, and the outcome of the often proclaimed judicial aversion to deal with such considerations is simply to leave the very ground and foundation of judgments inarticulate and often unconscious." ${ }_{3}$

It is important to remember that policy-driven decision-making aims to create a contemporary interpretation of what legislation under review should cover and achieve. A contemporary outlook could remedy inherent flaws in legislation relating to the fact that legislation is often static and sociopolitically out-ofdate. By emphasizing policy-driven decision-making, the Court has exercised

\footnotetext{
${ }^{81} \quad$ Ibid., the DPR's Defence.

82 William Blackstone, Commentaries on the Laws of England (Whitefish MT: Kessinger Publishing, 2007$), 69$.

83 Oliver W. Holmes, "The Path of the Law," Harvard Law Review 10 (1897): 457.
} 
its ideological function to maintain social order through the implementation of legal doctrines. ${ }^{84}$ It requires that the Court possesses substantive independence in deciding on cases where the judges have the freedom to consider not only the internal perspective but also the external determinacy of decision making. A judge has the sovereignty to uphold his perspectives while utilizing logical deduction and has a responsibility to discuss with his predecessors and review customs and the Constitution. ${ }^{85}$

While the court can make law and even policy, it has surpassed legislative bodies as the authentic author of law. To balance this instrumentalist approach, this paper revisits Posner's arguments on 'pragmatic instrumentalism' which he described as "a disposition to ground policy judgements on facts and consequences rather than on conceptualism and generalities." ${ }^{86}$ This is perhaps too practical and deficient in normativity and morality. It lacks a moral compass making pragmatism lose its noble purpose. Despite Posner often stating that his 'everyday pragmatism' is not derived from abstract values, his pragmatism is a mere concretisation of abstract values which also include morality. Thus, morality cannot be entirely alienated from the judicial function. As Justice Holmes famously stated in 1897, "the law, if not part of morality, is limited by it." ${ }^{87}$ This assertion synthesises the gap between instrumentalism and legalism by accepting a morality, a value that sets what the judges ought to be in decision-making.

This paper argues that the Court can only exercise its policy-driven decisionmaking approach where the text is insufficient for answering contemporary legal and social problems, including the imbalance between discriminatory political and social conditions. It is the 'morality' standard of judicial decision-making. The role of policy is to fill gaps in the law. It is a principled instrumentalist approach, which places judges as a creative counterparts of the legislators. Nevertheless, the judges must remain impartial and disinterested in politics.

84 Shapiro, Court: A Comparative and Political Analysis, 228.

85 Holmes, "The Path of the Law," 465.

86 Richard Posner, "Law, Pragmatism and Democracy: Reply to Somin," A Journal of Politics and Society 16, no. 4 (2004): 471.

87 Holmes, "The Path of the Law," 241. 


\subsection{Systematic Legislation-based Decision Making}

The second important decision ${ }^{88}$ was a judicial review to abolish Article 50A of the 2011 Constitutional Court Law. The article states: "The Court, in its judicial review, cannot utilize other related legislations as a constitutional touchstone, besides the constitution." The applicants argued that this article contradicted other constitutional provisions, particularly Article 22A, which states that "further technical aspects of constitutional norms and legislation's drafting will be provided in the legislation." This article specifies that the constitutional and legislative norms are inter-related. The Court decided by referring to its previous decision (precedent), ${ }^{89}$ that legislation is created as a legislative body's interpretation of the constitution. In other words, the constitution delegates its provisions to legislative drafting processes. Thus, legislation can be used as legal material in judicial review processes.

Through this decision, the Court reaffirmed that it has the ability to systematically consider and comment on legislation under review. The Court has the authority to sustain and deduce legal propositions. This attitude relates to the Court's technical function. However, none of the judges used a systematic decision-making approach in defending this article. This article argues that when a judge considers the interrelation between articles within one piece of legislation that of another piece of legislation, that judge is utilizing his internal perspective on the law. This intellectual exercise is rooted in legalist thinking, which states that law is a closed system of logical thinking and systematically constructed. This legal paradigm considers legislation, as one of the materials of the Justice in judicial review, has its objectivity. In other words, it contains analytical objectivity, which means that the state (written) law is an objectively logical-formal structure..$^{\circ 0}$

By utilising this internal systematic perspective on law, the legal construction may depart only depart from an internal viewpoint. A judge, during the decisionmaking process, is encouraged to trace the legislative intent of the legislation,

\footnotetext{
$\overline{88}$ Judicial Review of Constitutional Court Law, Decision of Constitutional Court No 49/PUU-IX/2011.

89 Ibid. The Court pointed Decision of Constitutional Court No 27/PUU- VII/2009 on Supreme Court Law.

go Kelsen, The Pure Theory of Law, 3.
} 
it being part of historical jurisprudence tenet. ${ }^{91}$ Statutory interpretation, in the civil law tradition, is referred to as the law finding (rechtsvinding) process in which a judge endeavours to 'find' a hidden legal question within the internal system of the law. The judges should not aim to 'make' the law because judges' main purpose is to investigate the ascertainment of the intent underlying the enactment of legislation..$^{22}$

This article argues that judges are not only bound to consider interrelated pieces of legislation but also to consider, elaborate, and understand diverse values of law and justice both in written law and customary laws. These principles and values will frequently be expressed in constitutional form. In instrumentalist thinking, decision making involves positive inquiry, not just normative analysis (moral and pre-existing legal reasoning). The court should seriously consider social policy, facts, 'consequences' and 'appropriateness' as the main references. Law-making is case-specific by nature. Under instrumentalism, the judge has to be the creative counterpart of the legislator by emphasizing multidisciplinary approaches to decision-making to assist the Justices where they have policy choice. ${ }^{93}$ In this decision, however, the Court did not clearly stress its philosophical stance.

It is also important to note that the applicants' demands for this decision were to strike down several articles in the 2011 Constitutional Law. One of the demands also related to the dismissal of judges from office. ${ }^{94}$ The Court decided the article under review was unconstitutional. This applicants' demand is closely related to judges' personal interest, which opens the discourse whether the Court ethically can decide the case closely relates to it or not.

\section{A MORAL COMPASS: JUDGES'PRUDENTIAL SELF- RESTRAINT}

As a consequence of the principle of constitutionalism, within which one of the central tenets stresses that all governmental institutions must have been

Lenhoff, "On Interpretive Theories," 325.

92 lbid.

93 Posner, "The Meaning," 21.

94 Constitutional Court Law, Article 87, Law No 8 of 2011 on Revision of Law No 24 of 2003. 
accountable for policies and decisions, the Court has a pivotal role in upholding constitutional supremacy. Technically, the Court is an institution established to control the main governmental institution's legal products, especially the Legislature (the DPR), which creates policies through legislation. In this regards, the independence of the judiciary and constitutionalism go hand in hand because a judiciary that has independence and impartiality in reviewing legislation would significantly elevate constitutional supremacy over political influences. On the contrary, if the judiciary cannot be trusted or acts in an unconstrained manner, it could stray from constitutionalism.

The Court, as a controller, also needs to work professionally and impartially to make sure that the law, not the subjectivity of judges, rules. No manner how involved in activism the Court is, when its judges can manifest their value judgments and preferences about matters related to constructing a decision, they should remain principled, and embrace consistency, and maintain an awareness of his personal conflicts of interest. The liberty to create and modify laws and exercise judicial prudential self-restraint, therefore, go hand in hand. The latter will not devolve into judicial supremacy if the former is not valued. ${ }^{95}$ The Court, judges in particular, must also exercise self-restraint with their liberty in creating and managing law. The judicial restraint is pivotal for avoiding the possibility of sliding toward 'juristocracy', when the judiciary has no limit of wisdom and discretion..$^{96}$

With regard to judicial self-restraint, Posner asserts that it is a contingent good, a time and place-bound, rather than absolute. ${ }^{97}$ This practical definition of restraint needs a normative and moral-based perspective in order to balance the freedom of judge in delivering his decisions. The value of morality requires impartiality in the application of good moral rules. In other words, freedom of judge needs to be exercised in a morally responsible way; judges must not have prejudiced towards or against any particular side or party, fair, unbiased..$^{8}$

\footnotetext{
95 William J. Haun, "The Virtues of Judicial Self-Restraint," National Affairs (2018). https://www.nationalaffairs.com/ publications/detail/the-virtues-of-judicial-self-restraint.

96 Edward McWhinney, Judicial Review in the English-speaking World (Toronto: University of Toronto Press, 1956$), 188$.

97 Posner, "The Meaning," 14.

98 "Oxford Constitutional Law," https://oxcon.ouplaw.com/view/10.1093/law-mpeccol/law-mpeccol-e338.
} 
Thus, instrumentalist judges must also employ impartial benevolence as the direct and sole determiner of the court's decisions. ${ }^{99}$ Impartiality construed as impartial benevolence is required because a judge has certain official and crucial roles in protecting the rule of law and constitutionalism. Impartiality is the core principle in relation to fairness and objectivity of judicial decisionmaking, ${ }^{100}$ its noble aim against bias and subjectivity is considered to be a principle of natural justice. In this regard, law is not only described merely as an instrument (as instrumentalist believes) but also as a responsible and accountable instrument. By merging practical aims of instrumentalism, including pro-poor and justice aspirations with prescriptive and moral-based perspectives of legalism through upholding to impartiality, a principled instrumentalist court can be constructed to answer more dynamic and problematics legal issues facing by post-authoritarian country like Indonesia, while upholding to the fidelity of law and constitutionalism value.

The Indonesian Constitutional Court practices restraint because it is aware of its position in the political arena. Technically, the 'conditional' decisions have manifested a self-imposed restriction on judicial decision-making by allowing the legislative and executive branches to develop government policy. This practice is known as political self-restraint, in which the judges give prudence to the practical political constraint involved with the exercise of judicial power. When the Court discussed and decided the constitutionality of Article 87 of the Constitutional Court on the judge's dismissal from office. In this case, the Court did not employ judicial restraint. When dealing with applicants' demands which were closely related to judges' personal interests, the Court firstly needs to identify which demands directly relate to judges' personal interests and which affect the Court as an institution. The Court must make decisions only based on the former, not the latter one. ${ }^{101}$

\footnotetext{
99 John Kekes, "Morality and Impartiality," American Philosophical Quarterly 18, no. 4 (1981): 295-303: 301.

100 Final Report by the Special Rapporteur L. M. Singhvi, The Administration of Justice and the Human Rights of Detainees: Study on the Independence and Impartiality of the Judiciary, Jurors and Assessors and the Independence of Lawyers, UN Doc. E/CN.4/Sub.2/1985/18.

101 Decision of Constitutional Court No 49, Dissenting opinion of Justice Harjono.
} 
In the cases where judges' conflict of interest is so strong, judges must prudentially exercise judicial and functional self-restraint in order to honor the integrity of the Court. The judges must show prudence regarding issues that could potentially hinder the Court's function as the guardian of the Constitution. The Court and its justices should be reminded that they have a responsibility to uphold constitutional values: justice and equality should be sought, without personal bias. Therefore, Justices should be free to exercise and elaborate on their individual liberties with a principled attitude.

\section{CONCLUSION}

This article concludes that the legal-politico actions of the Indonesian Constitutional Court cannot be strictly dichotomized into either legalism or instrumentalism. Three issues presented from two selected Court's decisions highlight the dynamic of the Court's decision-making reasoning in which the Court synthesised the two. In the first issue, the Court was allowed to surpass an applicant's demands for the sake of justice and create policy preferences to reconstructjusticiable legislation and policies. It is an instrumentalisminspired decision. Second, the issue of decision-based policymaking, the Court confirmed as an instrumentalist court. Nevertheless, the last issue on systematic legislation-based decision making, the Court stressed the inter-linked provisions on legislation that affirms legislation as a systematic legal building block which was inherently a legalism postulate. The most feasible model of the Indonesian Constitutional Court is that of a Principled Instrumentalist Court, where policy decisions guide the formation of legislation according to constitutional values. Still, the judges maintain prudential self-restraint as a moral compass for instrumentalist court. 


\section{BIBLIOGRAPHY}

Afandi, Fachrizal. The Justice System Postman: The Indonesian Prosecution System at Work. In The Politics of Court Reform: Judicial Change and Legal Culture in Indonesia, edited by Mellisa Crouch. Cambridge: Cambridge University Press, 2019.

Amsari, Feri. "Kuda Troya bagi MK [Troy's Horse strategy for demising the Constitutional Court]." Kompas, 4 April 2013.

Asshiddiqie, Jimly and Ahmad Syahrizal. Peradilan Konstitusi di Sepuluh Negara [Comparison of Ten Constitutional Courts in the World]. Jakarta: Sekretariat Jenderal dan Kepaniteraan Mahkamah Konstitusi RI, 2006.

Asshidiqie, Jimly. Konstitusi dan Konstitusionalisme di Indonesia [Constitution and Constitutionalism in Indonesia]. Jakarta: KonPress, 2006.

Austin, John. The Province of Jurisprudence Determined. London: Weidenfeld and Nicolson, 1954.

Basuni, Endy M. "Indonesia's Democracy Alive, but Needs More Kicks.” The Jakarta Post, 17 July 2019.

Bisariyadi. "Referencing International Human Rights Law in Indonesian Constitutional Adjudication." Constitutional Review 4, no. 2 (2018).

Blackstone, William. Commentaries on the Laws of England. Whitefish MT: Kessinger Publishing, 2007.

Bongiovanni, Giorgio. "Rechststaat and Grundnorm in the Kelsenian Theory." In Legal System and Legal Science. The Hague: ARSP, 1997.

Buana, Mirza Satria. "Hubungan Tarik-Menarik antara Kepastian Hukum dan Keadilan Substansial dalam Putusan MK [Substantive Justice and Legal Certainty on the Constitutional Court's decisions]." LLM Thesis, Islamic University of Indonesia, 2010. 
Butarbutar, Elisabeth N. "Kebebasan Hakim Perdata dalam Penemuan Hukum dan Antinomi dalam penerapannya ["Freedom of Judge: Law-finding and Antinomy]." Mimbar Hukum 23 (2011).

Butt, Simon. "Conditional Constitutionality, Pragmatism and the Rule of Law." Legal Studies Research Paper no. o9, 28, The University of Sydney, 2009. Butt, Simon and Tim Lindsey. "Economic Reform when the Constitution Matters: Indonesia's Constitutional Court and Article 33." Bulletin of Indonesian Economic Studies 44, 2008.

Coelho, Luiz F. “A Contribution to a Critical Theory of Law.” In Legal Philosophy: General Aspects: Concepts, Rights and Doctrines, edited by Michel Troper and Annalisa Verza. Steiner: 2002.

Constitutional Court Law. Law No 8 of 2011 on Revision of Law No 24 of 2003. Corcoran, Suzanne. "Theories of Statutory Interpretation." In Interpreting Statutes, edited by Suzanne Corcoran and Stephen Bottomley. Sydney: The Federation Press, 2005.

Decision of Constitutional Court No 27/PUU- VII/2009 on Supreme Court Law. Dressel, Bjorn. "Governance, Courts and Politics in Asia." Journal of Contemporary Asia 44 (2014).

Gifford, Donald. Statutory Interpretation. Sydney: The Law Book Company, 1990. Gray, John C. The Nature and Sources of the Law. New York: The Macmillan Company, 1938.

Hart, H.L.A. The Concept of Law. Oxford: Clarendon Press, 1994.

Haun, William J. “The Virtues of Judicial Self-Restraint.” National Affairs (2018). https://www.nationalaffairs.com/publications/detail/the-virtues-of-judicialself-restraint.

Hendrianto, Stefanus. "From the Humble Beginning Law to the Functioning Court: The Indonesian Constitutional Courts 2003-2008." Doctoral Dissertation, University of Washington, 2008. 
Holmes, Oliver W. “The Path of the Law." Harvard Law Review 10 (1897).

Internal Regulation of the Constitutional Court No o6 of 2005 on Procedural Code.

Isra, Saldi. “Gagasan Bernegara Yamin [Yamin's Suggestion on Nation-State].” Koran Tempo, 2 September 2014.

Judicial Review of State Electricity Law, Decision of Constitutional Court No oo1021-022/PUU-I/2003 (The Constitutional Court of the Republic of Indonesia). Judicial Review of Constitutional Court Law, Decision of Constitutional Court No 48/PUU-IX/2011 (The Constitutional Court of the Republic of Indonesia). Judicial Review of Constitutional Court Law, Decision of Constitutional Court No 49/PUU-IX/2011 (The Constitutional Court of the Republic of Indonesia). Kekes, John. "Morality and Impartiality." American Philosophical Quarterly 18, no. 4 (1981).

Kelsen, Hans. The Pure Theory of Law. California: University of California Press, 1967 .

Kirby, Michael. The Judges. Sydney: Australian Broadcasting Corporation, 1983. Lenhoff, Arthur. "On Interpretive Theories: A Comparative Study in Legislation.” Texas Law Review 27 (1949).

Lev, Daniel S. "The Politics of Judicial Development in Indonesia." Comparative Studies in Society and History 7, no. 2 (1965).

Lindsey, Tim. "Filling the Hole in Indonesia's Constitutional System: Constitutional Courts and the Review of Regulations in A Split Jurisdiction." Constitutional Review 4, no. 1 (2018).

Lindsey, Tim. "Indonesian Trial Process and Legal System, Background Notes." Unpublished Paper.

Manan, Bagir. "Kekuasaan Kehakiman [Judicial Power]." Paper presented at General Lecture, Airlangga University, 1 December 2011. 
Mavcic, Arne. The Constitutional Review. Den Bosch Netherlands: Book World Publications, 2001.

Mc Whinney, Edward. Judicial Review in the English-speaking World. Toronto: University of Toronto Press, 1956.

MD, Mohammad Mahfud. Politik Hukum di Indonesia [Policy-Oriented in Indonesia]. Jakarta: Rajawali Press, 2009.

Posner, Richard A. "The Meaning of Judicial Self-Restraint." Indiana Law Journal 59, no. 1 (1983).

Ratnapala, Suri. "The Idea of a Constitution and Why Constitutions Matter." Policy (Summer, 1999/2000).

Raz, Joseph. Ethic in The Public Domain: Essay in The Morality of Law and Politics. Oxford: Clarendon Press, 1996.

Roux, Theunis. "American Ideas Abroad: Comparative Implications of U.S. Supreme Court Decision-Making Models." International Journal of Constitutional Law 13, no. 1 (2015).

Roux, Theunis. “Indonesia's Judicial Review Regime in Comparative Perspective.” Constitutional Review 4, no. 2 (December, 2018).

Shapiro, Martin. Court: A Comparative and Political Analysis. Chicago: University of Chicago Press, 1981.

Shetreet, Shimon. "Judicial Independence: New Conceptual Dimensions and Contemporary Challenges." In Judicial Independence: The Contemporary Debate, edited by Jules Deschenes and Shimon Shetreet. M.Nijhoff: Hingham, 1995.

Siregar, Fritz E. "Indonesia Constitutional Court Interpretation Methodology (2003 - 2008)." Constitutional Review 1, no. 1 (2005).

Struchiner, Noel. “The Meaning of Justice.” In Legal Philosophy: General Aspects: Concepts, Rights and Doctrines: proceeding of the $19^{\text {th }}$ World Congress of the International Association for Philosophy of Law and Social Philosophy (IVR), edited by Michel Troper and Annalisa Verza. New York, June 1999. 
Summer, Robert. "Pragmatic Instrumentalism in Twentieth Century American Legal Thought - A Synthesis and Critique of our Dominant General Theory about Law and its Use." Cornell Law Review 66 (1981).

Tamanaha, Brian Z. Beyond The Formalist-Realist Divide: The Role of Politics in Judging. New Jersey: Princeton University Press, 2010.

Tempo.com. "Patrialis Akbar Charged for Accepting Bribes." Tempo, 13 June 2017, https://en.tempo.co/read/news/2017/o6/13/055884133/Patrialis-AkbarCharged-for-Accepting-Bribes.

The 1945 Constitution (as amended).

The Jakarta Post Online. "KPK names Akil Mochtar suspect of money laundering charges." The Jakarta Post, 26 October 2013, http://www.thejakartapost. com/news/2013/10/26/kpk-names-akil-mochtar-suspect-money-launderingcharges.html. 